\title{
APPLE FRUIT CHEMICAL THINNING IN CHIHUAHUA, MÉXICO
}

\section{RALEO QUÍMICO EN FRUTOS DE MANZANO EN CHIHUAHUA, MÉXICO}

\author{
David I. Berlanga Reyes, Alejandro Romo Chacón, Ángel R. Martínez Campos y \\ Víctor M. Guerrero Prieto*
}

Fisiología y Tecnología de Alimentos de la Zona Templada, Centro de Investigación en Alimentación y Desarrollo A. C. Av. Río Conchos s/n, Parque Industrial. Apdo. Postal 781. Cuauhtémoc, Chihuahua, México. Tel. 01 (625) 581-29-20.

*Autor para correspondencia (vguerrero51@ciad.mx)

\section{SUMMARY}

Chemical fruit thinning is a common practice in apple (Malus $x$ domestica Borkh.) orchards for achieving high quality fruits, reduced costs of hand-thinning and promote return of flowering. Hand thinning is a common and high cost practice, not only due to the labor involved, but also because seedling and vigorous clonal rootstocks result in large trees. The chemical thinning agents: Ethephon (ETH), Carbaryl (CB), Naphthalene acetic acid (NAA), 6Benzyladenine (6-BA), and fish oil were evaluated on 'Golden Delicious' and 'RedChief Delicious' apple trees in 2004 and 2005. Chemical thinning effect was compared with early and late handthinnings. Treatments were sprayed when the biggest fruit in the clusters was $10 \mathrm{~mm}$ in equatorial diameter. NAA showed the best effect in reducing final fruit set in both cultivars and years evaluated, with results comparable to those of early hand-thinning (thinned when king-fruit size was $10 \mathrm{~mm}$ ) in 'Golden Delicious' trees. In 'RedChief Delicious', fruit set reduction by NAA, fish oil and CB treatments was similar to early hand-thinned trees only in 2005. In 2005, time spent during supplementary hand-thinning in 'Golden Delicious' trees was reduced by chemical thinning treatments, except by fish oil; whereas in 'RedChief Delicious' only NAA $\mathrm{K}$-salt reduced it in 2004. An increase in fruit equatorial diameter was observed only in 2004 with NAA and fish oil. Alternate bearing, typical of 'Golden Delicious', was not diminished by these chemical thinning treatments.

Index words: Malus x domestica, fruit set, carbaryl, ethephon, naphthalene acetic acid, 6-benzyladenine.

\section{RESUMEN}

El raleo químico de frutos es una práctica regular en los huertos de manzanas (Malus $\mathbf{x}$ domestica Borkh.), y es llevada a cabo para obtener frutos de alta calidad, reducir el costo del raleo manual y promover el retorno de la floración. El raleo manual es una práctica común y de alto costo debido principalmente a que los manzanos se encuentran sobre porta-injertos de semilla o clonales vigorosos, que dan árboles grandes. Aquí se evaluó el efecto de los raleadores químicos: Etefón (ETH), Carbaril (CB), Ácido naftalenacético (NAA), 6-Benciladenina (6-BA) y aceite de pescado, en manzanos 'Golden Delicious' y 'RedChief Delicious' durante los ciclos 2004 y 2005. El efecto de los raleadores químicos se comparó con tratamientos de raleo manual temprano y tardío. La aspersión de los raleadores químicos se efectuó cuando el fruto mayor del racimo medía $10 \mathrm{~mm}$ de diámetro ecuatorial. El tratamiento con NAA mostró el mayor efecto en reducir el cuajado final de frutos en ambos cultivares $y$ ciclos evaluados, reducción que fue similar al raleo manual temprano (cuando el fruto mayor del racimo medía $10 \mathrm{~mm}$ ) en 'Golden Delicious'. En 'RedChief Delicious', la reducción en el cuajado de frutos obtenido por los tratamientos de NAA, aceite de pescado y CB fue similar al raleo manual temprano solamente en 2005. En 2005 el tiempo de mano de obra para el raleo manual complementario en los árboles 'Golden Delicious' fue reducido por los tratamientos químicos, excepto el aceite de pescado; en 'RedChief Delicious' solamente el NAA K-salt lo redujo en 2004. Se registró un incremento en el diámetro ecuatorial de frutos solamente en el ciclo 2004 con los tratamientos de NAA y aceite de pescado. La alternancia en la producción observada en 'Golden Delicious' no se logró reducir con los raleadores químicos.

Palabras clave: Malus x domestica, cuajado de frutos, ácido naftalenacético, carbaril, etefón, 6-bencil adenina.

\section{INTRODUCTION}

In order to reduce labor costs, enhance fruit size and return bloom, chemical fruit thinning is a regular practice in apple (Malus $x$ domestica Borkh.) fruit production (Yuan and Greene, 2000; Greene, 2002; Petracek and Silverman, 2003). Apple flower buds become initiated 30 to $40 \mathrm{~d}$ after blooming, a period when gibberellins (GA) from developing seeds in growing fruits inhibit floral initiation (Jackson, 2003; Ramírez et al., 2004). Because of this, fruit thinning should be performed within $28 \mathrm{~d}$ after full bloom to achieve a good fruit size and high return bloom (Koike et al., 2003). Abscission of immature fruits occurs frequently, varying in magnitude every year depending on fruit set, climatic conditions during flowering, nutritional status, carbohydrate availability, hormonal balance, or any combination of these factors (McArtney, 2005). 
Spur-type 'Red Delicious' and 'Golden Delicious' are some of the most widely planted apple cultivars in Cuauhtémoc, Chihuahua, México at an altitude of $2100 \mathrm{~m}$ (Guerrero et al., 2002). These cultivars are reported as difficult to thin (Marini, 2002). According to Dorigoni (2004) the activity of 6-benzyladenine (6-BA) is greatly reduced at high elevations, common a condition for other chemical thinners also. To overcome this problem, an aggressive fruit-thinning program is required.

Carbaryl (CB) and naphthalene acetic acid (NAA) are the most commonly used chemical thinners in the Chihuahua apple growing area. Carbaryl is a relatively mild, but effective thinner in spur-type 'Red Delicious' and 'Gala' trees (Marini, 1996), which must be sprayed when the largest fruit in the cluster is $10-12 \mathrm{~mm}$ in diameter (Ferree and Schmid, 2001). When CB is mixed with 6-BA + $\mathrm{GA}_{4+7}\left(\right.$ Accel $\left.^{\mathrm{TM}}\right)$, the thinning effect is comparable to hand-thinning in cvs. 'McIntosh' (Khanizadeh et al., 2004) and 'Fuji' (Ferree and Schmid, 2000). However, when $\mathrm{CB}$ is combined with 6-BA on cv. 'Redspur Delicious', the thinning effect can be excessive (Greene and Autio, 1994). CB usefulness is further limited because its toxicity to some predatory mites that are, important for integrated pest management (Hislop and Prokopy, 1981).

Reductions in photosynthesis have been reported in NAA-treated 'RedChief Delicious' trees (Stopar et al., 1997) and 6-BA-treated 'McIntosh' trees (Yuan and Greene, 2000). NAA has shown a strong thinning effect in spur-type 'Red Delicious' trees, but it may also induce an excessive development of pygmy fruits (Marini, 1996). In cv. 'Smoothee Golden Delicious' the lowest fruit set was obtained with $8 \mathrm{mg} \mathrm{L}^{-1}$ of NAA (Marini, 2002). An adequate thinning effect and increased fruit size, as well as a higher gain in fruit weight, can be reached with 6-BA than with either NAA or CB, because 6-BA can increase cell division rate in fruit cortex (Elfving and Cline, 1993; Greene and Autio, 1994; Wismer and Proctor, 1995). Also, 6-BA and CB have been more effective than NAA in increasing return bloom (Greene and Autio, 1994). In 'RedChief Delicious' Ethephon (ETH) has been an effective thinner when applied at concentrations $>500 \mathrm{mg} \mathrm{L}$ ${ }^{1}$, and ineffective at concentrations $<300 \mathrm{mg} \mathrm{L}^{-1}$ (Marini, 2004).

The objective of this study was to compare chemical thinning is to late hand-thinning, which is still a common practice at the high altitude of Chihuahua state, the main apple production area in México, with respect to labor for hand-thinning, fruit size and return bloom, in 'Golden Delicious' and 'RedChief Delicious' apple cultivars.

\section{MATERIALS AND METHODS}

Experiments were conducted in 2004 and 2005 on 15year-old trees of cvs. 'RedChief Delicious'/M.M.111 and 'Golden Delicious'/M.M. 106 in a commercial orchard in Cuauhtémoc, Chih., México. Trees were freestanding, trained as a central leader, and planted at $3.0 \times 4.3 \mathrm{~m}$. Trees for the experimental plots were visually selected in 2004. All trees were analyzed regarding, flower density and tree size, and no significant differences were found among them (data not shown). Tree vigor was determined by measuring the trunk cross-sectional area, while flower density was determined by using two representative branches per tree and expressed as flower clusters per square centimeter of cross-sectional branch area (BCSA, flower cluster $/ \mathrm{cm}^{2}$, Lombard et al., 1988). Treatments were applied on the same trees in both seasons. Thinning agents were sprayed at drip point with a motorized portable hand-gun sprayer, using $2 \mathrm{~L}$ of solution per tree. Sprayings were done in the morning at temperatures of 20-24 ${ }^{\circ} \mathrm{C}$. Each treatment was applied to five complete trees $(80 \%$ of the solution was sprayed to the upper two thirds of each tree). The mixture of hydrogen cyanamide (Dormex ${ }^{\mathrm{TM}}$ BASF, Germany), at $10 \mathrm{~mL} \mathrm{~L}^{-1}+$ mineral oil at $20 \mathrm{~mL} \mathrm{~L}^{-1}$ was applied $30 \mathrm{~d}$ before bloom to prevent the effect of a lack of sufficient chilling units during the previous Winter, to have a shorter and compact blooming period in 'Golden Delicious' trees.

When the cluster biggest fruit, also known as kingfruit (which is developed from the central flower of the cluster, and the first to open at bloom) reached $10 \mathrm{~mm}$ the trees were treated with the following thinning agents and dosages: Ethephon, $540 \mathrm{mg} \mathrm{L}^{-1}$ (Madurex $^{\mathrm{TM}}$, BASF, Micro Flo Co.); Carbaryl (CB), $480 \mathrm{mg} \mathrm{L}^{-1}$ (Sevin $80 \mathrm{PH}^{\mathrm{TM}}$, Aventis CropScience); NAA as potassium salt, $16.2 \mathrm{mg}$ $\mathrm{L}^{-1}$ (K-salt ${ }^{\mathrm{TM}}$ Fruit Fix 800 AMVAC Chem. Corp.); NAA as sodium salt, $18.6 \mathrm{mg} \mathrm{L}^{-1}$ (Fruitone $\mathrm{N}^{\mathrm{TM}}$ AMVAC Chem. Corp.); 6-benzyladenine, $95 \mathrm{mg} \mathrm{L}^{-1}$ (MaxCel $^{\mathrm{TM}}$ Valent BioSciences); and fish oil at $6 \mathrm{~mL} \mathrm{~L}^{-1}$ (a locally formulated chemical thinner, added with $5 \mathrm{~mL} \mathrm{~L}^{-1}$ of Bionex $^{\mathrm{TM}}$ GBM, México). An early hand-thinning treatment, applied when the king fruits measured $10 \mathrm{~mm}$, was included, leaving one fruit per cluster. A late handthinning at $60 \mathrm{~d}$ after full bloom was also included as control because it represents the local practice. In addition to these treatments, NAA $+\mathrm{CB}$ mixtures at concentrations of $5+240 \mathrm{mg} \mathrm{L}^{-1}$, and 6-BA $+\mathrm{CB}$ at $95+240 \mathrm{mg} \mathrm{L}^{-1}$, respectively, were included in 2005 . To achieve an even harvest distribution on each tree, all trees were handthinned to one fruit per cluster at $60 \mathrm{~d}(67 \mathrm{~d}$ for 'RedChief Delicious' in 2005) after full bloom. 
When king fruits reached a $10 \mathrm{~mm}$ diameter, thirty fruit clusters were labeled in each tree at application time. Fruits of labeled clusters were counted and expressed as fruits per 100 blossom clusters at 15 and $30 \mathrm{~d}$ after treatment in 'Golden Delicious' and at $30 \mathrm{~d}$ after treatment in 'RedChief Delicious' in 2004; whereas in 2005 they were counted at 15,30, and $43 \mathrm{~d}$ after treatment in both cultivars. Fruit set evaluation dates were expressed as days after full bloom (DAFB) and were variable because full bloom date is not the same for both cultivars. Time spent in hand-thinning a tree was directly related to its crop load, consequently, a high crop load per tree required more time to thin fruit. Time required to hand-thin the equivalent to $100 \mathrm{~kg}$ of fruit at harvest was determined for each tree to compare treatments. Pygmy fruits (equatorial diameter less than $5 \mathrm{~cm}$ ) at harvest were also evaluated in 'RedChief Delicious', since NAA is reported to induce this king of fruits when used in spur-type 'Delicious' trees (Greene and Autio, 1994). Yield per tree was recorded at harvest. Total soluble solids content was determined with an ATAGO $^{\text {TM }}$ model ATC-1E (Tokyo, Japan) refractometer. Flesh firmness was measured from two opposite sides of the fruits, with an electronic texture analyzer model TA-XT2i (Texture Technologies Corp., New York, USA). Average fruit size, as equatorial diameter in $\mathrm{mm}$, was determined on ten randomly harvested fruits in each tree, using a Cranston fruit gauge. Evaluation of return bloom was carried out during the following blooming season by comparing flower density in both consecutive seasons.

A completely randomized experimental design with five replications (complete trees) was used. Data were analyzed by Statistical Analysis System, version 6.12 (SAS Institute, 1996). Mean differences were determined by Tukey test $(\mathrm{P} \leq 0.05)$.

\section{RESULTS AND DISCUSSION}

\section{Fruit set}

The highest reduction in 'Golden Delicious' fruit set was found on the NAA-sprayed trees (both formulations, Fruitone $\mathrm{N}$ and K-salt) when evaluated at 45 DAFB, effect that was similar to that obtained in the early handthinned trees (Table1). Perhaps the induction of fruit drop required to achieve the benefits sought (larger fruits and higher return bloom) was too late, considering that Koike et al. (2003) reported that thinning at 28DAFB was already a late date for 'Golden Delicious'. Moreover, the hand-thinning practice locally used to adjust crop load, must be performed after the fruit drop induced by chemical thinning is already finished.
Contrary to our objectives the fish oil spraying produced the highest fruit set, even higher than late handthinned control in 'Golden Delicious', indicating that is not appropriate as a post-bloom thinner; Fish oil has been reported as an efficient bloom thinner (McArtney et al., 2006). Although other physiological processes, such as photosynthesis, were not evaluated in this experiment, other workers (Ju et al., 2001) reported that organic compounds, like soybean oil, can increase photosynthesis, carbohydrate availability and fruit set; such a statement might explain the increase in fruit set caused by fish oil in our experiment.

A reduction in fruit set was not observed on Ethephon (ETH) nor on 6-BA in both cultivars (Table 1). Similar the results were reported by Ferree and Schmid (2000) and Khanizadeh et al. (2004), who found that 6-BA (Ac$\mathrm{cel}^{\mathrm{TM}}$ ) by itself did not adequately thin 'Fuji' and 'McIntosh' trees. Marini (1996) showed that 6-BA was the least effective material for thinning spur-type 'Delicious' trees and found a greater efficiency of Ethephon when applied at $18 \mathrm{~mm}$ instead of $9 \mathrm{~mm}$ of king fruit diameter. The lack of effectiveness observed on 6-BA and ETH in our experiment might be due to the high altitude of the experimental orchard, according to Dorigoni (2004).

Sprayings with NAA and CB decreased fruit set in 'RedChief Delicious', although not as much as early hand-thinning (Table 1), a result that match those from Marini (1996) who reported that NAA is an efficient thinner on spur-type 'Delicious' trees.

\section{Yield and fruit quality}

Despite the significant reduction of final fruit set caused by NAA treatments on both cultivars, a yield reduction was not observed (Table 2). The late handthinning treatment at 60 DAFB standardized all treated trees at similar crop loads. The objective on this trial was to compare chemical thinning with the late hand thinning extensively used in this region.

NAA sprays increased mean fruit equatorial diameter in 'Golden Delicious' (Table 2), as a result of its efficiency as fruit thinner. Fish oil increased both fruit diameter and fruit set, a response that was observed only on 'Golden Delicious' in 2004. Possibly due to its thinning effect, the treatment NAA K-salt produced the biggest fruits at harvest in 'RedChief Delicious'. The increase in fruit size due to NAA sprays is well documented (Greene, 2005). The only significant reduction in fruit firmness was found when Ethephon was sprayed on 'Golden Delicious'. The higher flesh firmness obtained with Carbaryl 
(CB) on 'RedChief Delicious' might be explained by the smallest fruit size.

All thinning treatments reduced total soluble solids content on 'Golden Delicious' fruits, while on 'RedChief Delicious' the response was not the same (Table 2). It has been reported a decrease of soluble solids content on apples treated with 6-BA + CB (Khanizadeh et al., 2004) or NAA (Dennis, 2002) as fruit thinners. Highest total soluble solids content and the smallest fruit size were observed on CB-treated fruits on 'RedChief Delicious' (Table 2).

Table 1. Thinning effects on fruit set, return bloom the following year and time spent for hand-thinning in 'Golden Delicious' and 'RedChief Delicious' apple trees at Cuauhtémoc, Chihuahua, México. 2004 trials.

\begin{tabular}{|c|c|c|c|c|c|}
\hline \multirow[t]{2}{*}{ Treatment } & \multirow{2}{*}{$\begin{array}{c}\text { Rate } \\
\left(\mathrm{mg} \mathrm{L}^{-1}\right)\end{array}$} & \multicolumn{2}{|c|}{ Fruits per 100 clusters } & \multirow{2}{*}{$\begin{array}{c}\text { Flower clusters } / \mathrm{cm}^{2} \\
\text { BCSA in } 2005\end{array}$} & \multirow{2}{*}{$\begin{array}{c}\text { TSHT at } 60 \mathrm{DAFB} \\
(\mathrm{min} / \text { tree })\end{array}$} \\
\hline & & 28 DAFB & 45 DAFB & & \\
\hline \multicolumn{6}{|l|}{ 'Golden Delicious' } \\
\hline Late hand-thinned control & & $273 \mathrm{~b}$ & $172 \mathrm{~b}$ & $1.7 \mathrm{c}$ & $49.1 \mathrm{abc}$ \\
\hline Ethephon & 540 & $240 \mathrm{~b}$ & $151 \mathrm{~b}$ & $4.9 \mathrm{ab}$ & $l d$ \\
\hline Carbaryl & 480 & $259 \mathrm{~b}$ & $171 \mathrm{~b}$ & $1.9 \mathrm{c}$ & $53.4 \mathrm{ab}$ \\
\hline NAA (K-salt) & 16.6 & $235 \mathrm{~b}$ & $93 \mathrm{c}$ & $4.3 \mathrm{abc}$ & $34.4 \mathrm{c}$ \\
\hline NAA (Fruitone N) & 18.6 & 337 a & $109 \mathrm{c}$ & $4.1 \mathrm{abc}$ & $37.3 \mathrm{c}$ \\
\hline $6-\mathrm{BA}$ & 95 & $242 \mathrm{~b}$ & $152 \mathrm{~b}$ & $6.4 \mathrm{a}$ & $44.2 \mathrm{bc}$ \\
\hline Fish oil & $6 \mathrm{~mL} \mathrm{~L}^{-1}$ & $340 \mathrm{a}$ & $218 \mathrm{a}$ & $1.7 \mathrm{c}$ & $59.0 \mathrm{a}$ \\
\hline Early hand-thinning & & $87 \mathrm{c}$ & $87 \mathrm{c}$ & $3.6 \mathrm{abc}$ & $l d$ \\
\hline LSD & & 40.2 & 37.3 & 3.0 & 14.7 \\
\hline \multicolumn{6}{|l|}{ 'RedChief Delicious' } \\
\hline Late hand-thinned control & & & $259 \mathrm{a}$ & $4.0 \mathrm{~ns}$ & $49.5 \mathrm{a}$ \\
\hline Ethephon & 540 & & $272 \mathrm{a}$ & 6.5 & $34.9 \mathrm{ab}$ \\
\hline Carbaryl & 480 & & $202 \mathrm{bc}$ & 7.0 & $35.8 \mathrm{ab}$ \\
\hline NAA (K-salt) & 16.6 & & $177 \mathrm{c}$ & 7.1 & $24.8 \mathrm{~b}$ \\
\hline NAA (Fruitone N) & 18.6 & & $180 \mathrm{c}$ & 6.9 & $46.3 \mathrm{ab}$ \\
\hline $6-\mathrm{BA}$ & 95 & & $251 \mathrm{a}$ & 7.4 & $36.2 \mathrm{ab}$ \\
\hline Fish oil & $6 \mathrm{~mL} \mathrm{~L}^{-1}$ & & $240 a b$ & 7.3 & $29.3 \mathrm{ab}$ \\
\hline Early hand-thinning & & & $79 \mathrm{~d}$ & 5.9 & $l d$ \\
\hline LSD & & & 38.8 & 3.7 & 24.5 \\
\hline
\end{tabular}

Table 2. Thinning effect on yield, fruit equatorial diameter, firmness and total soluble solid content of 'Golden Delicious' and 'RedChief Delicious' apple trees grown at Cuauhtémoc, Chihuahua, México. 2004.

\begin{tabular}{|c|c|c|c|c|c|}
\hline Treatment & $\begin{array}{c}\text { Rate } \\
\left(\mathrm{mg} \mathrm{L}^{-1}\right)\end{array}$ & $\begin{array}{c}\text { Yield } \\
(\mathrm{kg} / \text { tree })\end{array}$ & $\begin{array}{l}\text { Equatorial fruit diameter } \\
\qquad(\mathrm{mm})\end{array}$ & $\begin{array}{c}\text { Fruit firmness } \\
(\mathrm{N})\end{array}$ & $\begin{array}{c}\text { Total soluble solid } \\
\left({ }^{\circ} \text { Brix }\right)\end{array}$ \\
\hline \multicolumn{6}{|l|}{ 'Golden Delicious' } \\
\hline $\begin{array}{l}\text { Late hand-thinned control } \\
\text { Ethephon } \\
\text { Carbaryl } \\
\text { NAA (K-Salt) } \\
\text { NAA (Fruitone N) } \\
\text { 6-BA } \\
\text { Fish oil } \\
\text { Early hand-thinning } \\
\text { LSD }\end{array}$ & $\begin{array}{c}540 \\
480 \\
16.6 \\
18.6 \\
95 \\
6 \mathrm{~mL} \mathrm{~L}^{-1}\end{array}$ & $\begin{array}{l}105.0 \mathrm{~ns} \\
142.5 \\
129.0 \\
111.2 \\
110.2 \\
125.9 \\
116.5 \\
122.0 \\
48.7\end{array}$ & $\begin{array}{l}65.4 \mathrm{~cd} \\
64.4 \mathrm{~d} \\
66.2 \mathrm{bcd} \\
67.5 \mathrm{ab} \\
68.5 \mathrm{a} \\
64.7 \mathrm{~cd} \\
68.2 \mathrm{a} \\
66.6 \mathrm{abc} \\
1.96\end{array}$ & $\begin{array}{l}62.3 \mathrm{ab} \\
64.5 \mathrm{a} \\
60.9 \mathrm{~b} \\
63.2 \mathrm{ab} \\
62.7 \mathrm{ab} \\
62.3 \mathrm{ab} \\
61.8 \mathrm{ab} \\
63.6 \mathrm{ab} \\
2.85\end{array}$ & $\begin{array}{l}13.3 \mathrm{a} \\
12.2 \mathrm{bc} \\
12.3 \mathrm{bc} \\
12.3 \mathrm{bc} \\
12.2 \mathrm{bc} \\
12.1 \mathrm{c} \\
12.1 \mathrm{c} \\
12.8 \mathrm{ab} \\
0.58\end{array}$ \\
\hline \multicolumn{6}{|l|}{ 'RedChief Delicious' } \\
\hline $\begin{array}{l}\text { Late hand-thinned control } \\
\text { Ethephon } \\
\text { Carbaryl } \\
\text { NAA (K-Salt) } \\
\text { NAA (Fruitone N) } \\
\text { 6-BA } \\
\text { Fish oil } \\
\text { Early hand-thinning } \\
\text { LSD }\end{array}$ & $\begin{array}{c}540 \\
480 \\
16.6 \\
18.6 \\
95 \\
6 \mathrm{~mL} \mathrm{~L}^{-1}\end{array}$ & $\begin{array}{l}58.9 \mathrm{~ns} \\
46.8 \\
37.8 \\
43.9 \\
49.4 \\
53.2 \\
43.2 \\
37.2 \\
27.6\end{array}$ & $\begin{array}{l}67.9 \mathrm{ab} \\
65.8 \mathrm{~b} \\
62.3 \mathrm{c} \\
70.0 \mathrm{a} \\
65.4 \mathrm{bc} \\
65.1 \mathrm{bc} \\
65.7 \mathrm{~b} \\
65.3 \mathrm{bc} \\
3.28\end{array}$ & $\begin{array}{l}66.3 \mathrm{e} \\
70.3 \mathrm{bcd} \\
76.9 \mathrm{a} \\
71.2 \mathrm{bc} \\
67.2 \mathrm{de} \\
73.4 \mathrm{ab} \\
68.5 \mathrm{cde} \\
73.8 \mathrm{ab} \\
3.91\end{array}$ & $\begin{array}{l}11.7 \mathrm{bc} \\
11.9 \mathrm{abc} \\
12.4 \mathrm{a} \\
11.4 \mathrm{~cd} \\
12.0 \mathrm{abc} \\
11.1 \mathrm{~d} \\
12.3 \mathrm{ab} \\
11.8 \mathrm{bc} \\
0.61\end{array}$ \\
\hline
\end{tabular}




\section{Return bloom}

At the beginning of the 2004 trials, selected trees had a mean flower density of six flower clusters $/ \mathrm{cm}^{2}$ of branch cross sectional area. In the next blooming period, 'Golden Delicious' treated with 6-BA induced the highest return bloom (Table 1), even though this treatment was not the most effective fruit thinner in 2004. Similar results were found by Greene and Autio (1994), Wismer and Proctor (1995) and Ramirez et al. (2004), who reported that exogenous cytokinins, as 6-BA, can increase flower differentiation and reduce alternate bearing on apple trees. Also, the promotion of flower differentiation by Ethephon may have induced a reduction on vegetative growth and inhibition of photosynthesis rate, causing a fruit thinning effect, as reported by Petracek and Silverman (2003) and by Untiedt and Blanke (2001). The 'Golden Delicious' trees submitted to treatments based on Carbaryl, fish oil or the late hand-thinned control showed an alternate bearing behavior (Table 1).

Return bloom in 'RedChief Delicious' was similar for all treatments, showing a regular bearing behaviour (Ta- ble 1); according to Jackson (2003), spur-type cultivars like 'RedChief Delicious' have a balance between bearing and nonbearing spurs in order to ensure regular cropping.

\section{Fruit set}

\section{5 trials}

Apple trees undergo several natural fruit drops. A significant natural fruit drop was observed on the control late hand-thinned trees after 42 and 53 DAFB on 'Golden Delicious' and 'RedChief Delicious', respectively (Table 3). The natural fruit drop will vary each year in response to those factors previously mentioned. Most of the chemical thinning sprays increased fruit drop due to an increase of the natural competition among fruitlets, a physiological phenomenon on which chemical fruit thinning is based (Dennis, 2002). Based on the three sequential fruit set evaluations, fruit drop was almost completed at 42 DAFB in 'Golden Delicious' and at 53 DAFB in 'RedChief Delicious'; it is then appropriate to perform the supplementary hand thinning practice at those times.

Table 3. Thinning effect on fruit set, return bloom the following year and time spent for hand-thinning on 'Golden Delicious' and 'RedChief Delicious' apple trees at Cuauhtémoc, Chihuahua, México. 2005.

\begin{tabular}{|c|c|c|c|c|c|c|}
\hline \multirow[t]{2}{*}{ Treatment } & \multirow{2}{*}{$\begin{array}{c}\text { Rate } \\
\left(\mathrm{mg} \mathrm{L}^{-1}\right)\end{array}$} & \multicolumn{3}{|c|}{ Fruits per 100 clusters } & \multirow{2}{*}{$\begin{array}{c}\text { Flower clusters } / \mathrm{cm}^{2} \\
\text { BCSA in } 2006\end{array}$} & \multirow{2}{*}{$\begin{array}{c}\text { TSHT at } 60 \text { DAFB } \\
(\mathrm{min} / \text { tree })\end{array}$} \\
\hline & & $27 \mathrm{DAFB}^{\dagger}$ & $42 \mathrm{DAFB}^{\dagger}$ & $56 \mathrm{DAFB}^{\dagger}$ & & \\
\hline \multicolumn{7}{|l|}{ 'Golden Delicious' } \\
\hline Late hand-thinned control & & $392 \mathrm{a}$ & $365 \mathrm{a}$ & $367 \mathrm{a}$ & $6.7 \mathrm{a}$ & $69.0 \mathrm{a}$ \\
\hline Carbaryl & 480 & $324 b$ & $266 \mathrm{~b}$ & $266 \mathrm{~b}$ & $4.4 \mathrm{abc}$ & $30.0 \mathrm{~b}$ \\
\hline NAA (K-salt) & 16.6 & $328 \mathrm{~b}$ & $156 \mathrm{~d}$ & $137 \mathrm{de}$ & $1.5 \mathrm{cde}$ & $14.4 \mathrm{~b}$ \\
\hline NAA (Fruitone N) & 18.6 & $382 \mathrm{a}$ & $206 \mathrm{c}$ & $177 \mathrm{~cd}$ & $3.9 \mathrm{abc}$ & $27.6 \mathrm{~b}$ \\
\hline 6-BA + Carbaryl & $95+240$ & $277 \mathrm{c}$ & $222 \mathrm{c}$ & $216 \mathrm{c}$ & 2.1 cde & 33.0 \\
\hline NAA (K-Salt) + Carbaryl & $5+240$ & $315 \mathrm{bc}$ & $204 c$ & $204 \mathrm{c}$ & $0.05 \mathrm{e}$ & $30.0 \mathrm{~b}$ \\
\hline Early hand-thinning & & $100 \mathrm{~d}$ & $100 \mathrm{e}$ & $100 \mathrm{e}$ & $5.5 \mathrm{ab}$ & $14.4 \mathrm{~b}$ \\
\hline LSD & & 40.2 & 40.5 & 40.2 & 2.9 & 20.7 \\
\hline 'RedChief Delicious' & & 38 DAFB & 53 DAFB & 66 DAFB & & \\
\hline 6-BA & 95 & $227 \mathrm{~b}$ & $158 \mathrm{bc}$ & $141 \mathrm{~cd}$ & 2.8 & $26.4 \mathrm{a}$ \\
\hline Fish oil & $6 \mathrm{~mL} \mathrm{~L}^{-1}$ & $210 \mathrm{~b}$ & $128 \mathrm{~cd}$ & $115 \mathrm{de}$ & 3.2 & $24.0 \mathrm{a}$ \\
\hline 6-BA + Carbaryl & $95+240$ & $278 \mathrm{a}$ & $217 \mathrm{a}$ & $204 \mathrm{a}$ & 3.6 & $31.8 \mathrm{a}$ \\
\hline NAA (K-Salt) + Carbaryl & $5+240$ & $278 \mathrm{a}$ & $172 \mathrm{~b}$ & $160 \mathrm{bc}$ & 3.7 & $29.4 \mathrm{a}$ \\
\hline Early hand-thinning & & $100 \mathrm{c}$ & $100 \mathrm{~d}$ & $100 \mathrm{e}$ & 3.7 & $7.2 \mathrm{~b}$ \\
\hline LSD & & 39.4 & 40.1 & 39.9 & 2.2 & 14.7 \\
\hline
\end{tabular}

Means with different letter in a column are statistically different (Tukey, 0.05). DAFB $=$ Days after full bloom; TSHT $=$ Time spent for hand-thinning by one person per tree with $100 \mathrm{~kg}$ of fruit at harvest; BCSA $=$ Branch cross sectional area. LSD $=$ Least significant differences. $\mathrm{ns}=$ No significant differences. 
Reduction of fruit set by most chemical thinners was easily visible at 27 DAFB for 'Golden Delicious' and at 38 DAFB for 'RedChief Delicious' (Table 3). It has been reported that a period of 10-30 DAFB is critical for fruit abscission, which is caused by reduction on photosynthate flow (Stopar, 1998). A blockage of photosynthate transportation between leaves and fruits has been reported as a thinning-mechanism for some chemical thinners (Dennis, 2002). In 2005 the fruit set reduction caused by chemical thinners was earlier than in 2004 (Tables 1 and 3), probably due to a higher fruitlet sensitivity to chemical thinning during the "off" year (year with a lower yield), as suggested by Lakso et al. (2006). Comparing the yield and flower density of the two evaluated years, it can clearly be seen the alternate bearing behavior of 'Golden Delicious' (Tables 1 to 4 ).

Except for fish oil, all treatments reduced the final fruit set in 'Golden Delicious', and also reduced the time spent for the supplementary hand-thinning practice (Table $3)$. This time reduction due to supplementary handthinning, represent a significant reduction in labor costs for growers, which fulfills one of the objectives estab- lished for these trials. Treatments with NAA alone and the combinations of Carbanyl with 6-BA or with K-salt resulted in the lowest fruit set, whereas the $\mathrm{K}$-salt by itself reduced fruit set at a similar level to the early handthinned trees (Table 3). Adding CB to the solution of 6BA increased the thinning effect as compared to 6-BA alone. Despite the significative reduction of fruit set, a high yield was obtained with K-salt (Table 4).

The lowest fruit set in 'RedChief Delicious' was obtained with NAA, CB and fish oil treatments (Table 3), which were similar to that obtained by early hand-thinned trees. The mixture of thinning agents reduced the effect of the same agents when applied separately. Marini (2002) also reported a reduction in thinning effect when $\mathrm{CB}$ was added to the NAA solution. In spite of the fruit set results, there was no reduction in time spent for the supplementary hand-thinning practice, because the 'RedChief Delicious' trees used in this experiment are compact trees (small size) and easier and faster to thin. Phytotoxicity symptoms, such as fruit russeting or leaf epinasty, were not observed on any treated tree, similar to 2004 evaluations.

Table 4. Thinning effect on yield, and fruit equatorial diameter, firmness and total soluble solid content on 'Golden Delicious' and 'RedChief Delicious' apple trees grown at Cuauhtémoc, Chihuahua, México. 2005.

\begin{tabular}{|c|c|c|c|c|c|}
\hline Treatment & $\begin{array}{c}\text { Rate } \\
\left(\mathrm{mg} \mathrm{L}^{-1}\right)\end{array}$ & $\begin{array}{c}\text { Yield } \\
(\mathrm{kg} / \text { tree })\end{array}$ & $\begin{array}{l}\text { Equatorial fruit diameter } \\
(\mathrm{mm})\end{array}$ & $\begin{array}{l}\text { Fruit firmness } \\
(\mathrm{N})\end{array}$ & $\begin{array}{l}\text { Total soluble solids } \\
\left({ }^{\circ} \text { Brix }\right)\end{array}$ \\
\hline \multicolumn{6}{|l|}{ 'Golden Delicious' } \\
\hline Ethephon & 540 & $73.4 \mathrm{ab}$ & $63.1 \mathrm{e}$ & $72.5 \mathrm{bc}$ & $13.2 \mathrm{~cd}$ \\
\hline Carbaryl & 480 & $58.4 \mathrm{bc}$ & $66.2 \mathrm{~cd}$ & $75.6 \mathrm{a}$ & $13.3 \mathrm{bcd}$ \\
\hline NAA (K-salt) & 16.6 & $99.2 \mathrm{a}$ & $66.6 \mathrm{~cd}$ & $69.8 \mathrm{~cd}$ & $12.4 \mathrm{e}$ \\
\hline Fish oil & $6 \mathrm{~mL} \mathrm{~L}^{-1}$ & $35.6 \mathrm{~cd}$ & $69.1 \mathrm{ab}$ & $68.5 \mathrm{de}$ & $13.5 \mathrm{bc}$ \\
\hline 6-BA + Carbaryl & $95+240$ & $55 \mathrm{bc}$ & $66.4 \mathrm{~cd}$ & $71.6 \mathrm{bc}$ & $13.1 \mathrm{~cd}$ \\
\hline NAA (K-salt) + Carbaryl & $5+240$ & $90.8 \mathrm{ab}$ & $64.9 \mathrm{de}$ & $65.8 \mathrm{ef}$ & $12.9 \mathrm{de}$ \\
\hline Early hand-thinning & & $56.8 \mathrm{bc}$ & $69.2 \mathrm{ab}$ & $69.8 \mathrm{~cd}$ & $13.8 \mathrm{~b}$ \\
\hline LSD & & 37.0 & 2.08 & 2.6 & 0.55 \\
\hline \multicolumn{6}{|l|}{ 'RedChief Delicious' } \\
\hline NAA (K-salt) & 16.6 & $47 \quad b c$ & $67.6 \mathrm{bc}$ & $62.7 \mathrm{c}$ & $12.8 \mathrm{~cd}$ \\
\hline NAA (Fruitone N) & 18.6 & $74.9 \mathrm{a}$ & $70.3 \mathrm{ab}$ & $64.9 \mathrm{bc}$ & $11.9 \mathrm{e}$ \\
\hline $6-\mathrm{BA}$ & 95 & $67.2 \mathrm{ab}$ & $67.1 \mathrm{c}$ & $67.2 \mathrm{abc}$ & $12.0 \mathrm{e}$ \\
\hline Fish oil & $6 \mathrm{~mL} \mathrm{~L}^{-1}$ & $78.5 \mathrm{a}$ & $70.9 \mathrm{a}$ & $65.8 \mathrm{abc}$ & $12.1 \mathrm{e}$ \\
\hline 6-BA + Carbaryl & $95+240$ & $36.2 \mathrm{c}$ & $66.7 \mathrm{c}$ & $64.5 \mathrm{bc}$ & $13.1 \mathrm{bc}$ \\
\hline NAA (K-Salt) + Carbaryl & $5+240$ & $42.6 \mathrm{c}$ & $66.2 \mathrm{c}$ & $65.4 \mathrm{abc}$ & $13.6 \mathrm{ab}$ \\
\hline Early hand-thinning & & $42.0 \mathrm{c}$ & $64.7 \mathrm{c}$ & $69.8 \mathrm{a}$ & $12.2 \mathrm{de}$ \\
\hline MSD & & 24.5 & 2.9 & 4.87 & 0.70 \\
\hline
\end{tabular}

${ }^{\dagger}$ Means with different letter in a column are statistically significant different (Tukey, 0.05). LSD $=$ Least significant differences. 


\section{Yield and fruit quality}

An alternate bearing behaviour was observed on 'Golden Delicious', especially in late hand-thinned control, Carbaryl and fish oil treated trees. Highest yield was obtained with K-salt and 6-BA treatments, even with the low fruit set observed with K-salt. Similar results were found on 'RedChief Delicious' with Fruitone $\mathrm{N}$ and fish oil, which showed the highest yield values despite the low fruit set achieved (Table 4).

Fruit equatorial diameter in 'Golden Delicious' was greatest for the late hand-thinned control. This effect was related to the low yield registered in this treatment. It is well known that there is a negative correlation between the number of fruits per tree and the fruit size (Jackson, 2003). However, the greatest fruit size observed for the late hand-thinned control trees in 'RedChief Delicious' (Table 4) can not be explained in the same manner as with 'Golden Delicious'.

Highest fruit firmness was observed on Carbaryl and the late hand-thinned control treatments, whereas lower values were for 6-BA treated trees (Table 4). Late handthinned control produced fruits with higher total soluble solids content (Table 4), probably due to a high leaf:fruit ratio since these trees had a lower crop load. A similar behaviour was observed in 2004, despite a similar crop load (Table 2). Thinning treatments did not induce pygmy fruits at harvest in 'RedChief Delicious' (data not shown).

\section{Return bloom}

A high return bloom was observed on late handthinned control, Carbaryl and fish oil treatments as a result of the alternate bearing behavior of 'Golden Delicious'. Ethephon and 6-BA failed to produce a satisfactory return bloom in the second year of evaluation, like they did in 2005 (Tables 1 and 3). Even with the effectiveness of the chemical thinning treatments (Table 3), return bloom for 'RedChief Delicious' trees did not show any effect. A reduction in return bloom for all 'RedChief Delicious' trees was observed, may be due to a slightly higher yield per tree in 2005 than in 2004.

\section{General conditions}

The late season hand thinning, as commercially done, is an strategy devised to minimize the impact of late season frosts. Therefore, growers thin once in the Spring when frost probabilities are scarce. Some responses were common to both years; for example, time spent in hand- thinning was $50 \%$ lower in K-salt-treated trees than in late hand-thinned control trees for 'RedChief Delicious' (Table 1). Also, phytotoxicity effects such as fruit russeting or leaf epinasty, neither pygmy fruits were not observed in any of the chemical thinners tested.

\section{CONCLUSIONS}

Lowest fruit set was obtained with naphthalene acetic acid sprayed as chemical thinner in cultivars 'Golden Delicious' and 'RedChief Delicious', and sometimes fruit set was similar to that obtained with early hand-thinning. This reduction of fruit set did not affect yield or fruit quality at harvest. In 'Golden Delicious', all chemical treatments except fish oil, reduced the time spent for performing the supplementary hand thinning, and this reduced the cost of hand-thinning in 2005; this occurred in 'RedChief Delicious' in 2004 only when sprayed with Ksalt. Alternate bearing observed on 'Golden Delicious' trees was not reduced by the chemical thinners.

\section{ACKNOWLEDGEMENTS}

To the Fundación PRODUCE Chihuahua and the Regional Agricultural Fruit Growers Association of the State of Chihuahua (UNIFRUT) for providing financial support, and to Mr. Abraham Olfert Krahn for kindly supplying trees for experimental plots and other supplies used in this project.

\section{BIBLIOGRAPHY}

Dennis Jr F G (2002) Mechanisms of action of apple thinning chemicals. HortScience 37:471-473.

Dorigoni A (2004) Apple fruit thinning, alternative in northern Italy. The Compact Fruit Tree 37:26-29.

Elfving D C, R A Cline (1993) Benzyladenine and other chemicals for thinning 'Empire' apple trees. J. Amer. Soc. Hort. Sci. 118:593-598.

Ferree D C, J C Schmid (2000) Chemical thinning 'Fuji' apple in the Midwest. J. Amer. Pomol. Soc. 54:61-67.

Ferree D C, J C Schmid (2001) Chemical thinning 'Gala' apple in the Midwest. J. Amer. Pomol. Soc. 55:109-113.

Greene D W (2002) Chemicals, timing, and environmental factors involved in thinner efficacy on apple. HortScience 37:477-481.

Greene D W (2005) Effects of repeated yearly application of chemical thinners on 'McIntosh' apples. HortScience 40:401-403.

Greene D W, W R Autio (1994) Combination sprays with Benzyladenine to chemically thin spur-type 'Delicious' apples. HortScience 29:887-890.

Guerrero V M, J A Orozco, A Romo, A A Gardea, F J Molina, B Sastré, J J Martínez (2002) The effect of hail nets and ethephon on color development of 'RedChief Delicious' apple fruit in the highlands of Chihuahua, Mexico. J. Amer. Pomol. Soc. 56:132-135.

Hislop R G, R J Prokopy (1981) Integrated management of phytophagous mites in Massachustts (USA) apple orchards. 2. Influence of pesticides on the predator Amlyseius fallacis 
(Acarina: Phytoseiidae) under laboratory and field conditions. Protection Ecol. 3:157-172.

Jackson J E (2003) Biology of Horticultural Crops. Biology of Apples and Pears. Cambridge University Press. United Kingdom. pp:268-340.

Ju Z, Y Duan, Z Ju, A Guo (2001) Corn oil emulsion for early bloom thinning of trees of 'Delicious' apple, 'Feng Huang' peach, and 'Bing' cherry. J. Hort. Sci. Biotech. 76:327-331.

Khanizadeh S, Y Groleau, J Deell, I Ali, F Saad, D Rekika (2004) Effects of Sevin XLR Plus and Accel on pre-and post-harvest quality and yield of 'McIntosh' apples. J. Amer. Pomol. Soc. 58:29-35.

Koike H, H Tamai, T Ono, I Shigehara (2003) Influence of time of thinning on yield, fruit quality and return flowering of 'Fuji' apple. J. Amer. Pomol. Soc. 57:169-173.

Lakso A N, T L Robinson, D W Greene (2006) Integration of environment, physiology and fruit abscission via carbon balance modeling - implications for understanding growth regulator responses. Acta Hort. 727:321-326.

Lombard P B, N W Callan, F G Dennis Jr, N E Looney, G C Martin, A R Renquist, E A Mielke (1988) Towards a standardized nomenclature, procedures, values, and units in determining fruit and nut tree yield performance. HortScience 23:813817.

Marini R P (1996) Chemically thinning spur 'Delicious' apples with carbaryl, NAA, and ethephon at various stages of fruit development. HortTechnology 6:241-246.

Marini R P (2002) Thinning 'Golden Delicious' and spur 'Delicious' with combinations of Carbamates and NAA. HortScience 37:534-538

Marini R P (2004) Combinations of ethephon and Accel for thinning 'Delicious' apple trees. J. Amer. Soc. Hort. Sci. 129:175181.
McArtney S J (2005) Next steps in crop load management research: escaping vagaries of weather, hormones and carbon balance. The Compact Fruit Tree 38:14-16.

McArtney S J, J Palmer, S Davies, S Seymour (2006) Effects of lime sulfur and fish oil on pollen tube growth, leaf photosynthesis and fruit set in apple. HortScience 41:357-360.

Petracek P D, F P Silverman (2003) A history of commercial plant growth regulators in apple production. HortScience 38:937942.

Ramírez H, J Torres, A Benavides, J Hernández, V Robledo (2004) Fruit bud initiation in apple $c v$ Red Delicious linked to giberellins and cytokinins. Rev. Soc. Quim. Mex. 48:7-10.

SAS Institute Inc. (1996) The SAS System for Windows.SAS Institute Inc. Cary, NC, USA.

Stopar M (1998) Apple fruitlet thinning and photosynthate supply. J. Hort. Sci. Biotech. 73:461-466.

Stopar M, B L Black, M J Bukovac (1997) The effect of NAA and BA on carbon dioxide assimilation by shoot leaves of spur-type 'Delicious' and 'Empire' apple trees. J. Amer. Soc. Hort. Sci. 122:837-840

Untiedt R, M Blanke (2001) Effects of fruit thinning agents on apple tree canopy photosynthesis and dark respiration. Plant Growth Reg. 35:1-9.

Wismer P T, J T A Proctor (1995) Benzyladenine affects cell division and cell size during apple fruit thinning. J. Amer. Soc. Hort. Sci. 120:802-807.

Yuan R, D W Greene (2000) Benzyladenine as a chemical thinner for 'McIntosh' apples. I. Fruit thinning effects and associated relationships with photosynthesis, assimilate translocation, and nonstructural carbohydrates. J. Amer. Soc. Hort. Sci. 125:169-176. 